\title{
Corporate Ethics and Governance in the Liberalised Indian Telecom Sector
}

\author{
Dr. Gopika.G.G* \\ "Lecturer, Department of Commerce and Management Studies, A.C.Kunhimonhaji Memoria I.C.A College.
}

\begin{abstract}
The corporate ethics and corporate governance depend on various aspects in the functions of management. Thus the apt application of the theories of ethics and corporate governance paves the way for the success of a concern. Thus the success of an organization is vested with the hands of customers. They are not aware of the unethical practices within the organization. A good concern should be aware of business ethics which are necessary for economic growth. If there is a perfect corporate governance in an organization, it is considered that there exists maximum utilization of available men, material and money. Only through the implementation of business ethics successfully, the goodwill is achieved by the concern. Telecom infrastructure is treated as a crucial factor to realize the socio economic objectives in India. With the recognition of nonaffordability of implementing better infrastructural facilities the policy of liberalization in this sector came into existence. This led to the emergence of private operators in the cellular service and WLL service. Public sector undertakings like BSNL and MTNL also started offering cellular services along with basic wire line services. Liberalisation and privatization in service sector lead to corporate failure is the experience in general. Through the corporatization of Telecom sector in India competition, deregulation and technological changes were there, which could bring changes on the way of functions of telecom sector. As a result of aggressive moves by competitors entering from other sectors and rapid change in telecoms' established value chains, operators need to respond to these changes with the migration of value from charging for minutes of usage to carrying rising volumes of data across networks.
\end{abstract}

\section{Introduction}

Telecom infrastructure is treated as a crucial factor to realize the socio economic objectives in India. With the recognition of non-affordability of implementing better infrastructural facilities the policy of liberalization in this sector came into existence. Thus BSNL was formed on $1^{\text {st }}$ October, 2000. This led to the emergence of private operators like Reliance Telecom Ltd., Bharathi Airtel, BPL Mobile Communications Ltd., Idea Cellular, etc. in the cellular service and WLL service. Public sector undertakings like BSNL and MTNL also started offering cellular services along with basic wire line services.

Liberalisation and privatization in service sector lead to corporate failure is the experience in general. Through the corporatization of Telecom sector in India competition, deregulation and technological changes were there, which could bring changes on the way of functions of telecom sector. A notable revolution in this sector as the part of globalization is that the replacement of old ordinary telephone services, in accordance with the changes in the needs of the consumers. The Telecom Sector is going through a phase of phenomenal growth in India and the number of mobile manufacturers has been increasing rapidly, particularly in the last one year. The number of homegrown telecom manufacturers has grown up rapidly starting new phase of low cost handsets. Starting companies like Micromax and Maxx mobiles have given tough fight to the majors like Nokia and Samsung in the low cost handset markets which these biggies have failed to counter back. The major reason why these home grown companies have been winning against their global counterparts is mainly on cost and features. These companies import the handsets cheaply from China, brand them on their names and sell into the market at cheap prices.

\section{Telecom Revolution in India}

During the ongoing era of economic reforms, Telecom sector reforms has been a success story, under a scenario of competitive growth shared by the public and private sectors, on the one hand, and the regulated environment, on the other. The planners had realized early that without a globally competent and efficient telecommunication system, the process of globalization of the economy would be incomplete. Hence, this was perhaps the first sector that got adequate attention during the post reforms era and also bore outstanding results. From an outdated and inefficient system, the telecom sector has emerged as state of the art system of international standard within a decade. But the revolution has just begun. Telecommunication is among the prime support services needed for rapid growth and modernization of various sectors of the economy, apart from improving the quality of life. 
Till the year 1988, India was among the large number of Asian and African countries that had a tele-density of less than one, at 0.52. This density in the developed countries of North America and Western Europe was about 50. At that time countries like Pakistan, China, Malaysia and Brazil has tele-density of 0.7, 0.78, 7.37 and 5.5, respectively. But in terms of growth of direct telephone lines, during the years 1979 to 1989, the growth rate was 8.4 percent, which was much higher than the growth rate of 3.5 percent in the United States of America, 5.7 percent in Europe and 5 percent in the entire world. The reason was obvious. In real terms, before midseventies, tele-density in India was virtually negligible and it was at around that time that the country began to experience real growth in this sector.

\section{Corporate governance}

Strong corporate governance facilitates effective management and monitoring of telecom and helps ensure that we fulfill our responsibilities to our stakeholders-including investors, customers, employees, and the community. The Board of Directors should adopt guidelines that define their fiduciary duties and expected standards of conduct. The Board of Directors should also adopt corporate governance guidelines that reflect the Board's current governance practices and the Board's commitment to ensuring its effectiveness. The Nominating and Governance Committee of the Board should identify qualified potential Board members and nominates directors to be considered for election by our stockholders or in special elections by the Board to fill vacancies or newly created directorships.

The Board should possess the following minimum qualifications:

- The highest personal and professional ethics and integrity.

- Sound business judgment.

- The absence of conflicts of interests that would impair the individual's ability to exercise independent judgment and otherwise discharge his or her fiduciary obligations.

- Sufficient time to devote to their responsibilities as a Board member.

- Requisite knowledge, skills, and experience to understand our business.

- Ability to meet NASDAQ and other requirements with respect to independence and financial literacy.

Other qualifications that they consider include:

- Significant senior management or leadership experience.

- Industry experience.

- Strategic vision.

- Diversity in perspective.

\section{Corporate Ethics}

Telecom should adopt a complaint procedure whereby employees can report concerns about accounting, audit matters or related ethical issues. Telecom should adopt a Code of Ethics for Directors and a more detailed Code of Conduct for the employees. Executive Vice President, General Counsel and Regulatory Policy should serve as Compliance Officer. An Ethics and Integrity Council composed of the Compliance Officer and other senior officers should oversee the investigation and disposition of matters reported to the Compliance Office. The company should adopt the code of ethics for directors and employees to promote honest and ethical conduct and to deter wrong doing. Any person who has information concerning any violation of the Code by any director or employee should promptly bring such information to the attention of the Company's Integrity \& Ethics Council by sending a fax.

\section{Ethical problems in telecommunication}

As a result of aggressive moves by competitors entering from other sectors and rapid change in telecoms' established value chains, operators need to respond to these changes with the migration of value from charging for minutes of usage to carrying rising volumes of data across networks. It is believed that operators should now raise their sights to target revenues from new services that tap into rising demand. Operators need to adapt their business models to a wider ecosystem and make firm decisions about which revenue sources they are going to target within that broader environment. In light of developments such as the rapidly intensifying competition for consumers' spending, the revenue growth potential in the enterprise segment remains high in comparison to the consumer market. To exploit this potential, business models for enterprise customers have to embrace new approaches to provisioning alongside collaborative approaches to service development and delivery. The following are some of the ethical problems in telecom sector :

\section{(i)Quickening technology and reshape brand affinities}

The dominance by the technology players reflects the extent to which quickening technology cycles across both the consumer and enterprise segments are impacting consumers' everyday working habits and lifestyles, and reshaping their brand affinities. The operators' fixed and mobile networks are now a platform for 
access to a wide number of sectors and services, such as television, retail and banking. As this explosion in online/mobile applications gathers pace, disruptive players are leveraging their rising brand values to extend their service propositions. At the same time, devices are playing a pivotal role in shaping the mobile customer experience. As these changes in customers' mindset - and behavior continue, and seemingly accelerate operators have an absolute need to adapt their service offerings and customer experience to reflect these shifts in order to sustain and build customer engagement. These responses should be supported by clear communication with customers on the value of the network and on the effort and investment required to provide high-quality services. Network quality is often taken as a given, but it shouldn't be. Service quality is not just about the device or application; it is also about the network infrastructure without which these elements would never work. If operators worldwide can get this message across to customers, then they will be able to improve perceptions of added value - including price, quality and convenience - and to work the proven levers of brand strength in telecommunications, including high trust and credibility. With the number of high-speed mobile connections globally continuing to grow rapidly getting the timing of new investments right is critical for achieving the targeted returns. Operators need to understand clearly how infrastructure upgrades relate to customer demand, competitor actions and government industrial policies. This can be supported through better leveraging and optimization of legacy networks to complement network/service availability. It requires confronting challenges such as uncertainties in supply and demand amid factors such as spectrum releases, soaring usage of high-bandwidth applications and shifting market structures as network sharing and consolidation continue to gain ground. Also, many operators have multi-technology strategies and fail to fully understand the complementarities and optimization factors between them. Operators need to tackle all these challenges while continuing to invest in network infrastructure.

\section{(ii) Lack of information as per demand}

To drive profitable customer propositions, companies need accurate, timely and comprehensive business intelligence and customer analytics, underpinned by the right operational support and billing systems. Not having all these elements in place threatens operators' efforts to increase time-to-market and build customercentricity. It can also undermine the potential returns on their ongoing investments. The issue now is both more holistic and more pressing. The requirement to ensure the right systems and processes are in place is being given added urgency by a widening gap between what operators know they need to do and what they are achieving. Time-to-market is increasingly important. Operators' time-to-market for new services should be improved. BSNL cannot bring products to market quickly. Repurposing customer data in new ways can enable operators to improve their market positioning, through advantages such as better business intelligence — for example, anticipating market and customer changes before competitors — and reusing network data for collaborative partners and sector verticals.

\section{(iii) Challenges around policy}

The challenges and uncertainties around the policy approaches to new market structures include shifting regulatory standpoints on wholesale broadband access pricing, and the trend toward imposing network separation as a pro-competition tool in super-fast broadband. Going forward, new spectrum releases will shape 4G market structures - and the rules vary from market to market in areas such as spectrum caps and trading. In new and emerging areas such as mobile money, regulatory jurisdictions and policies continue to lag behind the technology — a challenge compounded by the "broadband as a human right" lobby. On top of these uncertainties, there is continued regulatory pressure on legacy parts of the business, such as MTRs and roaming. In combination, these issues have pushed regulatory frameworks to the top of the list of challenges facing ISPs. And in tough fiscal conditions, operators know that telecoms can be a rich source of government taxation as well as a focus for government investment. These factors are creating an urgent need for greater regulatory certainty - and, alongside greater clarity and consistency from regulators, achieving this will require operators to engage with a wider set of stakeholders. Consolidation in markets worldwide will continue to impact pricing and investment, and the need to fund next generation access and spectrum releases will require broad market consensus on the regulatory position. And overarching questions remain about the impact of the net neutrality agenda across the whole of the technology, media and telecoms ecosystem.

\section{(iv) Privacy, Security and Resilience}

As mobile phones evolve into personal data hubs, end users are facing privacy and security dangers that are escalating and multiplying, as threats converge from a range of environments, including SMS, cloud, Web 2.0 and mobile apps. As a result, customers are now as concerned about data integrity as call quality. Carriers should be well placed to help users address these threats, since they are regarded as more trustworthy than other service providers, such as social networks. Yet customers hold operators responsible for threats or attacks from third parties and suppliers - even including mobile malware and rogue apps. At the same time, privacy concerns 
hamper service innovation. For example, location-sensitive data can support advertising-based revenue models but may raise concerns around customers' privacy. To manage the resulting risks effectively, operators should bear in mind that concepts of digital rights are an emotive issue for customers and that national security considerations are rising in importance. The picture is further complicated by the fact that the nature and scale of security concerns vary for different customers and stakeholders, such as consumer, enterprise and government. At the same time, changing definitions of privacy and security are creating new responsibilities for the sector. In response, operators need to work closely with governments to define clearly their responsibilities regarding content and data, such as anti-terrorism measures and content for children.

For keeping ethics within the organisation, all Directors and Employees should:

i. Act honestly and ethically on the performance of their duties at the Company.

ii. Avoid actual or apparent conflicts of interest between personal and professional relationships or between the individual's other business or professional interests and his or her duties and responsibilities to the Company, including the avoidance of any investment, interest or association that interferes, might interfere or might appear to interfere with the individual's independent exercise of judgment in the Company's best interest.

iii. Provide full, fair, accurate, timely and understandable disclosure in reports and documents that the Company files with, or submits to, the SEC and in other public communications by the Company.

iv. Comply with rules and regulations of federal, state and local governments and other private and public regulatory agencies that affect the conduct of the Company's business and the Company's financial reporting.

v. Act in good faith, responsibly, with due care, competence and diligence, without misrepresenting material facts or allowing independent judgment to be subordinated.

vi. Respect the confidentiality of information acquired in the course of work, except when authorized or legally obligated to disclose such information.

vii. Share knowledge and maintain skills relevant to carrying out the individual's duties within the Company.

viii. Proactively promote ethical behavior as among peers, work groups and colleagues in the work environment and community.

ix. Promptly bring to the attention of the Audit Committee any information concerning (a) significant deficiencies in the design or operation of internal controls which could adversely affect the Company's ability to record, process, summarize and report financial data, or (b) any fraud, whether or not material, that involves management or other employees who have a significant role in the Company's financial reporting, disclosures or internal controls.

x. Accept personal accountability for adherence to this Code.

\section{II. conclusion}

Due to huge market potential, even public sector undertakings like BSNL \& MTNL have also begun offering cellular services apart from basic wireline services. Corporate governance and business ethics describes the application of theories of ethics and corporate governance in various business situations. The apt application of these theories paves the way for the success of a concern. It depends on various aspects in the functions of management also. As per the new marketing concepts customer satisfaction should be the ultimate aim. Thus the success of an organization is vested with the hands of customers. They are not aware of the unethical practices within the organization. A good concern should be aware of business ethics which are necessary for economic growth. If there is a perfect corporate governance in an organization, it is considered that there exists maximum utilization of available men, material and money. Only through the implementation of business ethics successfully, the goodwill is achieved by the concern.

\section{References}

[1]. Amit Mitra (1994): “The telecom tussle”, Business India, January 3-16.

[2]. Ashok. V. Deshai (2006): "India's Telecommunication Industry", Sage publications India.pvt Ltd, New Delhi-110017.

[3]. Chalam. G.V(2005): “Quality of Services in Indian Telecom sector: users perception - An Assessment, " the ICFAI Journal of Managerial Economics, May, Vol III , No.2

[4]. Chowdary. T.H (2000): “Towards People-Oriented Telecom Services", Economic and Political weekly, $29^{\text {th }}$ July.

[5]. Damodharan.K.V. (2000): "Financial management in department of telecom", The management Accountant, April, Vol:35, No:4.

[6]. Rekha Jain: "A Review of The Indian Telecom Sector," http://siteresource.world bank.org.

[7]. www.trai.govt.in

[8]. www.dot.gov.in 